\title{
ДАЙДЖЕСТ ОNLINE-ЗАХОДІВ ІНСТИТУТУ ПРОБЛЕМ ВИХОВАННЯ НАПН УКРАЇНИ
}

https://doi.org/10.37472/2707-305X-2020-2-1-7-3

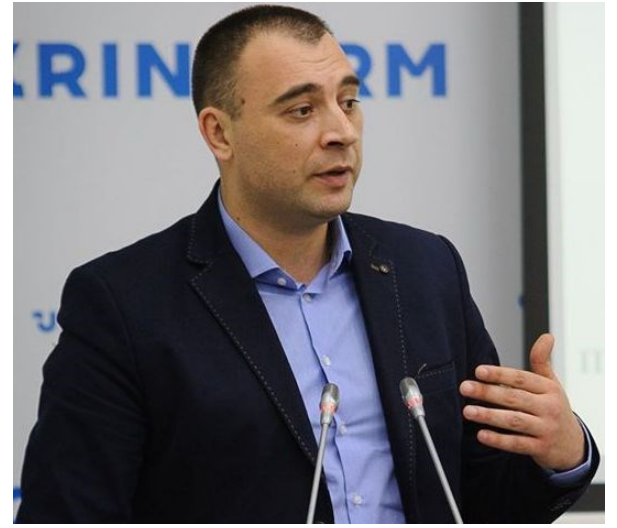

\section{МАЛИНОШЕВСЬКИЙ}

Руслан Васильович

кандидат педагогічних наук, старший науковий співробітник, заступник директора з наукової роботи Інституту проблем виховання Національної академії педагогічних наук України, м. Київ, Україна

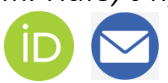

Анотація. Інститут проблем виховання НАПН України, як і кожна наукова установа України, в умовах пандемії COVID-19 був вимушений радикально трансформувати операційну діяльність. Якщо донедавна вона розгорталася в умовах фізичного часу та простору, то карантинні заходи сприяли переведенню більшої частини наукової активності у віртуальний простір. Вимушена і неминуча діджиталізація сприяла повноцінному використанню тих можливостей, які виникли в результаті закриття закладів освіти на період карантину, соціального дистанціювання, заборони масових заходів. Оскільки в таких умовах опинилося абсолютно все населення, вчені Інституту проблем виховання НАПН України розгорнули системну наукову комунікацію з педагогами та батьками через офріційну сторінку у Facebook ma на YouTube-каналі. Ця стаття є коротким дайджестом наукової активності за понад 30 днів карантину.

Ключові слова: вебінар; Iнститут проблем виховання НАПН України; дошкільна освіта; критичне мислення; навчання online; цілі сталого розвитку.

Пандемія COVID-19, закриття кордонів, карантин, самоізоляція, згортання ділової активності, уповільнення економічних і соціокультурних процесів, соціальне дистанціювання та соціальна відповідальність - це те, що сьогодні становить нашу реальність, видозмінює нашу дійсність. Це загроза і виклик. Виклик для людства, держави, інституцій, особистості. Але водночас це і «вікно» можливостей для трансформації усталених практик, осучаснення операційних процесів.

Запровадження в Україні надзвичайної ситуації, посилення протиепідемічних заходів стало і викликом, і «вікном» нових можливостей для Інституту проблем виховання НАПН України Наукові дослідження, предметним полем яких $€$ виховна проблематика, передбачають не просто написання текстів, а й невпинну суб'єкт-суб'єктну взаємодію, зануреність науковця у виховну ситуацію, особистісну присутність на експериментальному майданчику, де верифікуються наукові положення й виховні технології. Цілком очевидно, що в умовах запровадження карантину така елементарна наукова співпраця стали нездійсненною. Зрозуміло, що з цієї ж причини унеможливилися і заплановані масові науково-практичні заходи традиційного формату. Це спонукало до зміни моделей наукової взаємодії і переорієнтації на комунікацію online з цільовою аудиторією через соціальну мережу у Facebook. Так, за цей період можна виділити кілька видів активностей, що системно розгорталися на офіційній сторінці Інституту у Facebook. Починаючи з відкриття доступу до презентацій із актуальних питань позашкільної освіти (Корнієнко, 2020; Литовченко, 2020), підготовлених співробітни- 
ками лабораторії позашкільної освіти, та серії відеопорад батькам щодо безпеки дітей підліткового віку в Інтернеті від провідного співробітника лабораторії інституційного виховання, доктора педагогічних наук, старшого наукового співробітника Людмили Вікторівни Гончар (2020а, 2020b), Інститут проблем виховання НАПН України лише посилював наукову комунікацію у цифровому просторі. 331 березня ц.р. відкрилася серія стрімів, відеодоповідей і відеороликів, пропонованих для педагогічної та батьківської громадськості, і звичайно ж вебінарів, проведення яких технологічно уможливив кандидат педагогічних наук Олександр Васильович Базелюк.

Розпочала серію вебінарів провідний науковий співробітник лабораторії позашкільної освіти Інституту проблем виховання НАПН України, кандидат педагогічних наук, старший науковий співробітник Ольга Леонідівна Пруцакова (2020), яка 31 березня ц.р. провела вебінар «Цілі сталого розвитку у шкільній екологічний освіті». Доповідачка розкрила пріоритети сучасного розвитку суспільства, які $є$ глобальним орієнтиром, та основні напрями сучасного дискурсу, що обумовлений імплементацією цілей сталого розвитку.

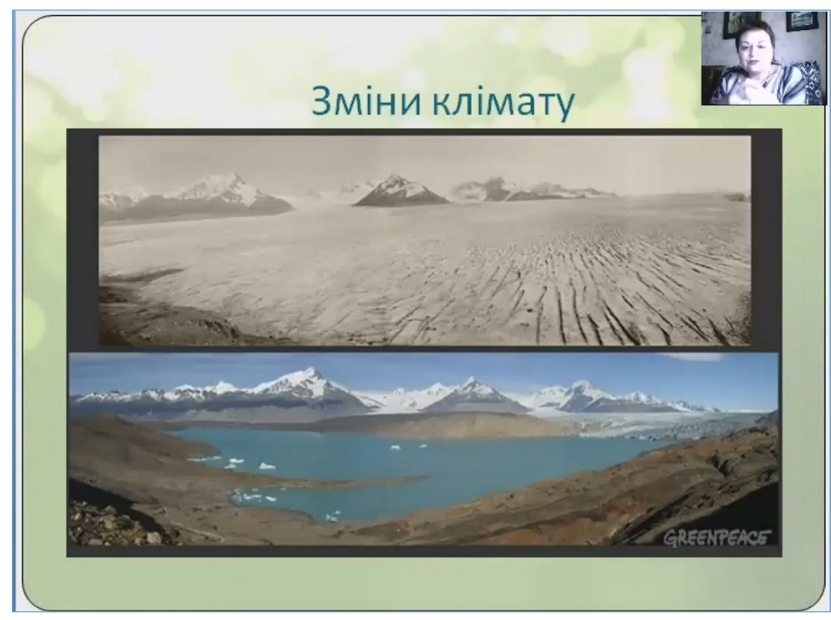

Цього ж дня відбувся вебінар «Дієві прийоми розвитку критичного мислення», презентований завідувачкою лабораторії морального, громадянського та міжкультурного виховання Інституту проблем виховання НАПН України, кандидатом педагогічних наук, старшим науковим співробітником Наталією Вікторівною Харченко (2020), яка у невимушеному і дружньому спілкуванні 3 аудиторією звернула увагу на критичне мислення, котре сьогодні є однією із ключових компетенцій сучасної людини. Проте наскрізною лінією виступу став пошук відповіді на запитання: що жє критичне мислення, які межі його застосування, чим власне критичне мислення відрізняється від суми знань і в чому саме проявляється самостійність мислення? Пошук відповідей на ці запитання, закономірно, переріс у демонстрацію прийомів як, власне, сприяти розвитку критичного мислення у дитини.

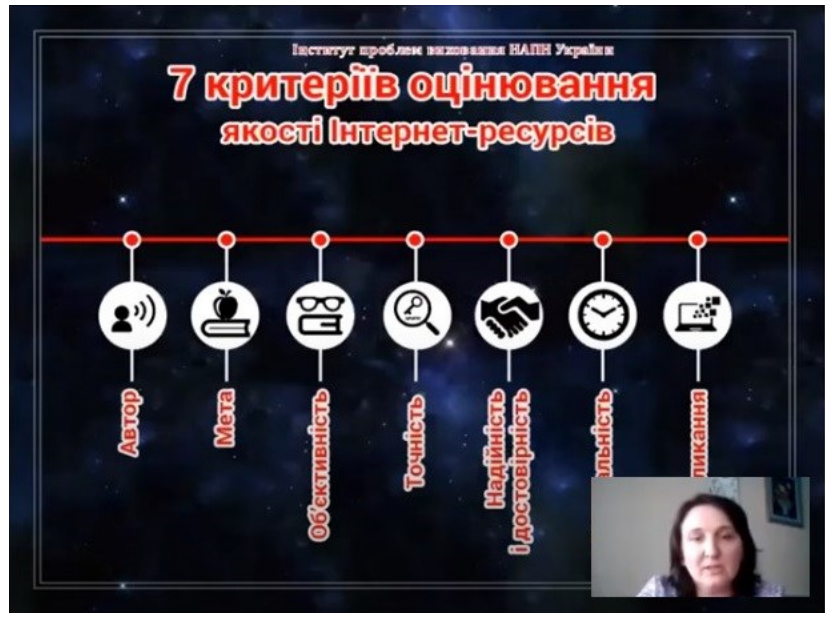

2 квітня ц.р. старший науковий співробітник лабораторії морального, громадянського та міжкультурного виховання Інституту проблем виховання НАПН України, кандидат психологічних наук Любов Михайлівна Сокол (2020) провела вебінар «Психологічна готовність до соціальної взаємодії в освіті». Зокрема, під час спілкування було акцентовано, що психологічна готовність це інтегральна якість особистості та необхідна підстава для соціальної взаємодії. Орієнтуючись на психолого-педагогічний загал, доповідачка розкрила ті методики, які дадуть змогу педагогам відслідкувати емоційні індикатори дитини - такі, як почуття провини, примусу, невиконаного обов'язку, що унеможливлюють соціальну взає модію і самореалізацію. Окремо було продемонстровано роль гідності як ядра психологічної готовності.

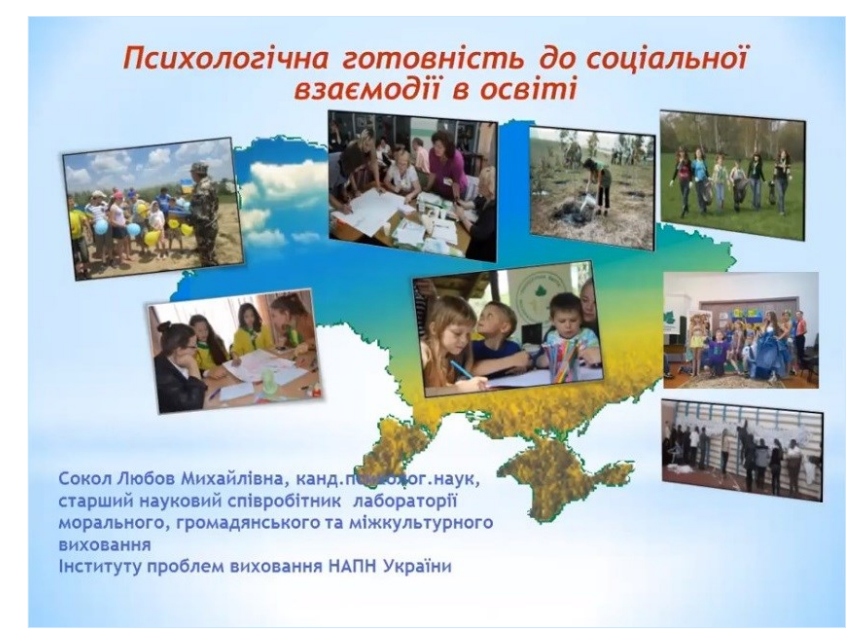


Завершенням першої тижневої сесії вебінарів став вебінар «Соціальні проєкти дитячих громадських організацій», проведений старшим науковим співробітником лабораторії морального, громадянського та міжкультурного виховання Інституту проблем виховання НАПН України Оленою Вікторівною Пащенко (2020). У бесіді 3 аудиторією вчена розкрила типологію проєктів, прикметні ознаки та алгоритми розроблення соціальних проєктів. Найголовніше, задаючи запитання, навіщо потрібен проєкт і що він дає зростаючій особистості, візуалізувала виховний потенціал соціального проєкту.

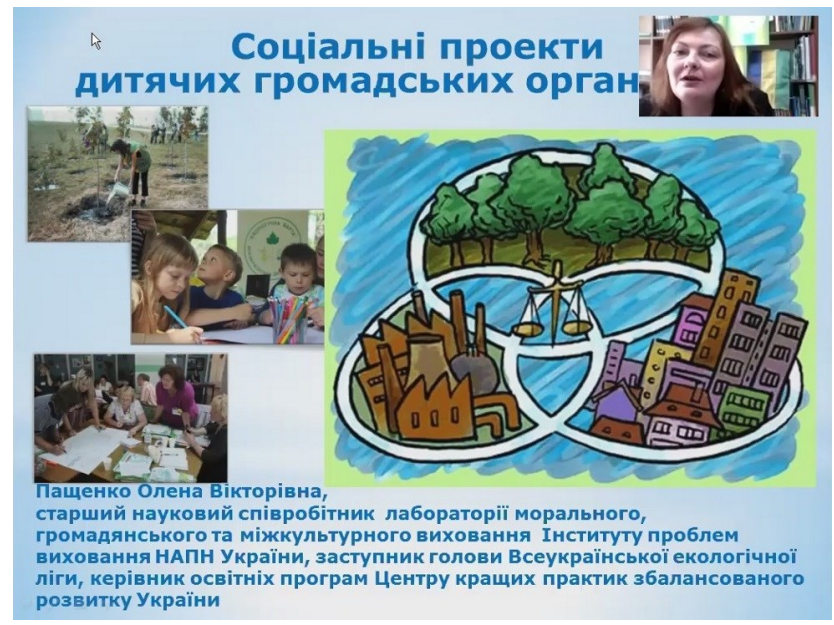

Якісно відмінним можна вважати стрім, що був проведений 6 квітня ц.р. науковим співробітником лабораторії естетичного виховання та мистецької освіти Інною Сергіївною Райт (2020). У чому ж полягає унікальність стріму? Його нетиповість насамперед зводиться до проблематики, оскільки темою для проведення вебінару стало запитання «як навчити грати на фортепіано Online?».

Очевидно, що загальним трендом останніх десятиліть, а після запровадження карантинних заходів у масштабах цілого світу, є і буде дистанційне навчання. Якщо стосовно усталених навчальних дисциплін і процесу їх дистанційного вивчення вже склалася певна узвичаєна думка, то в контексті мистецьких реалій невідомо, чи $\epsilon$ реальним online-навчання на музичному інструменті, коли гаджети стають посередниками між учнем та вчителем? Саме на прикладі гри на фортепіано, виходячи з власного досвіду викладання в умовах соціального дистанціювання, Інна Райт демонструвала, як вчителю музики можна працювати в умовах дистанційного навчання, у чому полягають особливості та труднощі цього процесу і чи реально дистанційно навчитися грати?
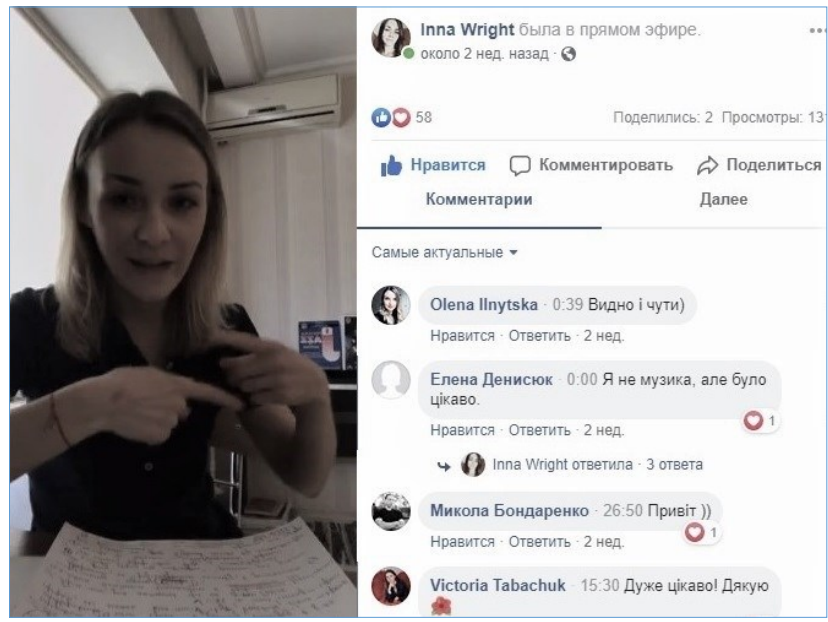

Абсолютно окремим блоком наукової комунікації Інституту проблем виховання НАПН України з громадськістю стали вебінари, тематичні відеоролики та відеодоповіді 3 актуальних питань дошкільної освіти та виховання. І тут, вочевидь, доречним буде відійти від строгої хронології подій, а точково розставити акценти на знакових речах.

у рамках цього блоку на ҮouTube-каналі Інституту та офіційній сторінці Інституту у Facebook було розміщено серію коротких відеороликів за темою «Підготовка дитини 3-го року життя до декоративної діяльності (за авторським альбомом «Вчимося у майстрів: ліпимо, малюємо. Третій рік життя» і методичними рекомендаціями)», які підготувала провідний науковий співробітник лабораторії дошкільної освіти і виховання Інституту проблем виховання НАПН України, кандидат педагогічних наук Вікторія Валентинівна Рагозіна (2020а; 2020b; 2020с; 2020d; 2020е). Ця відеосерія є своєрідним майстер-класом для вихователів закладів дошкільної освіти. Вона охоплює як виховну пропедевтику декоративної діяльності у ранньому віці, так і магістральні моменти авторської методики, що

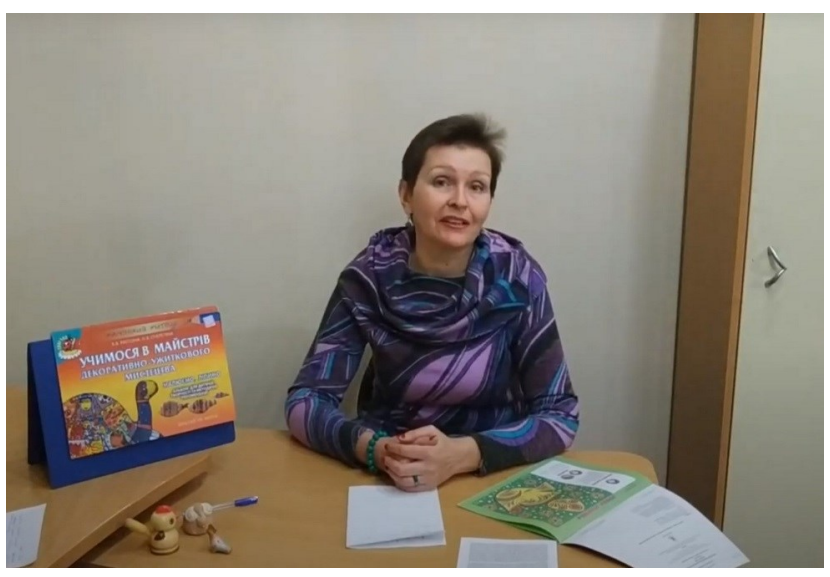


втілена в авторському альбомі «Вчимося у майстрів: ліпимо, малюємо. Третій рік життя».

Якщо ж аналізувати статистику переглядів створеного 31 березня ц.р. ҮouTube-каналу Інституту проблем виховання НАПН України, то станом на 15 квітня ц.р. налічувалося 5,1 тис. переглядів. Хочу наголосити, що ҮouTube-канал як інструмент популяризації Інституту створено менше як місяць тому, а вже сьогодні він має аудиторію, яка стабільно зростає. Сервіси аналітики, які пропонує платформа YouTube, дають змогу виокремити топ-3 відео.

Лідером за переглядами $€$ вебінар, який відбувся 1 квітня ц.р. Завідувач лабораторії дошкільної освіти і виховання Інституту проблем виховання НАПН України, кандидат педагогічних наук, доцент Ольга Дмитрівна Рейпольська провела вебінар «Формування у старших дошкільників соціально-комунікативної компетентності» (Гавриш \& Рейпольська, 2020). У доповіді та подальшому діалозі з вихователями закладів дошкільної освіти та батьками обговорювали актуальні питання соціалізації старших дошкільників, методи та технології їх соціалізації у реальному освітньому процесі. Актуальність проблематики, що була порушена під час вебінару, сприяла не лише активному включенню у діалог глядачів, а й подальшому перегляду цього запису на YouTube-каналі. Зокрема, станом на 15 квітня ц.р. налічувалося 3,4 тис. переглядів.

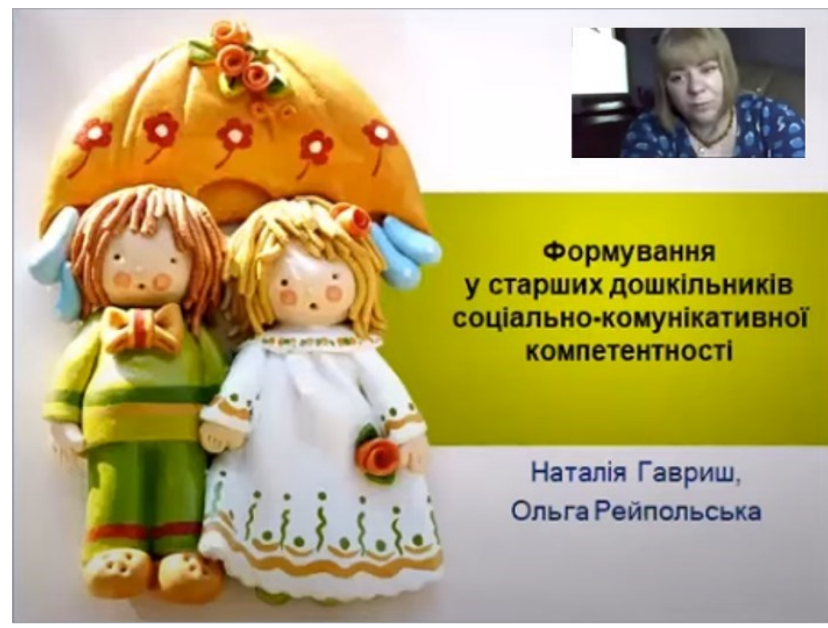

Другим відео, що входить в топ-3, є відеодоповідь, яку підготувала Ольга Дмитрівна Рейпольська «Проєктуємо освітнє середовище для індивідуального розвитку дитини» (2020), де представлено наукову рефлексію щодо створення освітнього середовища як безпечної освітньо-виховної екосистеми, яка належить дитині і $€$ сприятливою для її особистісного розвитку.
Третє найпопулярніше відео - це запис вебінару «Гармонізація дитячо-батьківських взаємин: модель свободи дитини», проведеного 15 квітня ц.р. Ведуча - Наталія Василівна Гавриш (2020), доктор педагогічних наук, професор, провідний науковий співробітник лабораторії дошкільної освіти і виховання Інституту проблем виховання НАПН України, порушила одвічну проблему родинного виховання і виховання загалом. Зокрема, меж свободи у вихованні, які мають бути кордонами між «можна» і «не можна»; що заважає будувати правильні стосунки 3 дітьми і як їх зробити гармонійними?

А вже 16 квітня ц.р. доктор педагогічних наук, професор, старший науковий співробітник лабораторії дошкільної освіти і виховання Інституту проблем виховання НАПН України Лариса Іванівни Зайцева (2020) провела вебінар «Використання активних методів у навчанні дітей дошкільного віку математики». Цей вебінар наразі $€$ наймасовішим вебінаром, одночасно участь у якому взяло 85 осіб.

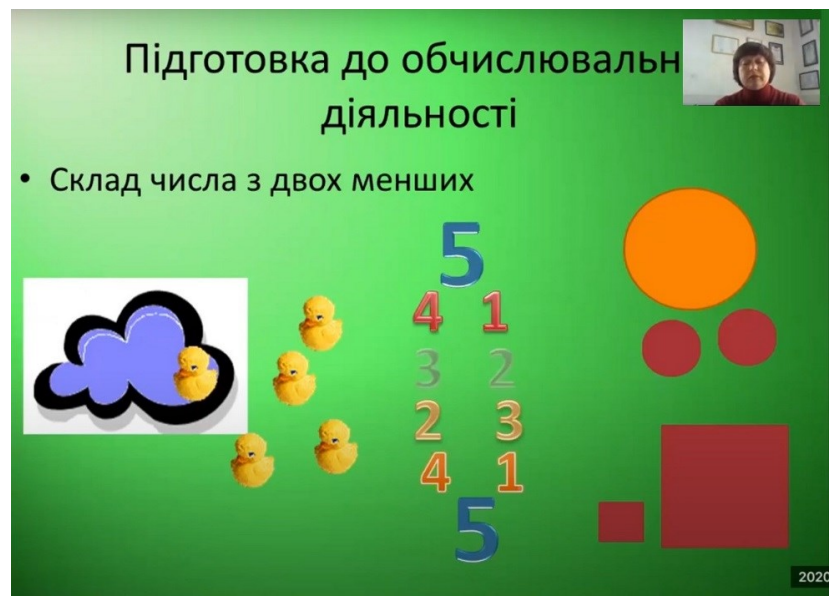

Цілком очевидно, що такий невеликий дайджест не вичерпує всієї повноти робіт, які здійснюють науковці Інституту проблем виховання НАПН України. Але він демонструє приклад системного розгортання комунікації і оперативного реагування на актуальні проблеми сьогодення. Виклики часу створюють своєрідне «вікно» можливостей. Попереду заплановані нові стріми та вебінари.

\section{СПИСОК ВИКОРИСТАНИХ ДЖЕРЕЛ}

Гавриш, Н., \& Рейпольська, О. (2020, 2 квітня). Формування у старших дошкільників соціальнокомунікативної компетентності [Відео]. YouTube. https://www.youtube.com/watch?v=qOXWeld5u0 
Гавриш, Н.В. (2020, 16 квітня). Гармонізація взаємин [Відео]. YouTube. https://www.youtube.com/watch?

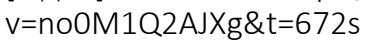

Гончар, Л.В. (2020а, 26 березня). Небезпечні он-лайн ігри. Рекомендації для педагогів та батьків щодо безпеки дітей підліткового віку в інтернеті [Відео]. Facebook. https://www.facebook.com/watch/? $v=653100522205370$

Гончар, Л.В. (2020b, 1 квітня). Обережно: кібербуллінг! На допомогу класним керівникам та шкільним психологам по роботі з батьками щодо безпеки дітей підліткового віку в інтернеті [Відео]. Facebook. $\mathrm{v}=558380011455799$

Зайцева, Л.І. (2020, 15 квітня). Використання активних методів у навчанні дітей дошкільного віку математики [Відео]. YouTube. https:// www.youtube.com/watch?v=7D5h8uqE1mg

Інститут проблем виховання НАПН України (n.d.). Відео [YouTube канал]. https://www.youtube.com/ channel/UCOxBrxLe0_ar5cukEjal_bA/videos

Інститут проблем виховання НАПН України (n.d.). Головна [Facebook сторінка]. https:// www.facebook.com/ipv.org.ua/

Корнієнко, А.В. (2020, 24 березня). Методичні рекомендації до написання навчальних програм 3 позашкільної освіти [Відео]. Facebook. https:// www.facebook.com/watch/?v=206597320619015

Литовченко, О. (2020, 24 березня). Актуальні аспекти модернізації позашкільної освіти [Відео]. Facebook. $\mathrm{v}=919990258432823$

Пащенко, О.В. (2020, 3 квітня). Соціальні проєкти дитячих громадських організацій [Відео]. YouTube. https://www.youtube.com/watch?v=sMg8vPgMsbw

Пруцакова, О.Л. (2020, 31 березня). Цілі сталого розвитку у шкільній екологічний освіті [Відео].
YouTube. $\mathrm{v}=3 \mathrm{GscxYT4} \mathrm{eHM}$

Рагозіна, В.В. (2020а, 6 квітня). Чи можливо реалізовувати декоративну діяльність у ранньому віці? [Відео]. YouTube. https://www.youtube.com/watch? $\mathrm{v}=9 \mathrm{Mz} \cup 907 \mathrm{rXj4}$

Рагозіна, В.В. (2020b, 7 квітня). Як підготувати дитину 3-го року життя до декоративної діяльності [Відео]. YouTube. https://www.youtube.com/ watch? $v=$ tr1WtwK_f4g

Рагозіна, В.В. (2020с, 8 квітня). В чому «родзинка» авторського альбому «Вчимося у майстрів: ліпимо, малюємо. Третій рік життя» [Відео]. YouTube. https://www.youtube.com/watch? $\mathrm{V}=\mathrm{XUA5YO4hqZk}$

Рагозіна, В.В. (2020d, 8 квітня). Особливості авторської методики [Відео]. YouTube. https:// www.youtube.com/watch?v=org8VMWaEB4

Рагозіна, В.В. (2020е, 9 квітня). Специфріка методів і прийомів для успішної декоративної діяльності дітей раннього віку [Відео]. YouTube. https:// www.youtube.com/watch?v=98iNBVKKrXO

Райт, І.С. (2020, 6 квітня). Як навчити грати на фортепіано Online? [Відео]. Facebook. https:// www.facebook.com/100006903017466/videos/ vb.100006903017466/2738932079680199/

Рейпольська, О.Д. (2020, 13 квітня). Проєктуємо освітнє середовище для індивідуального розвитку дитини [Відео]. YouTube. https:// www.youtube.com/watch?v=17zgcMrxbMc\&t=12s

Сокол, Л.М. (2020, 2 квітня). Психологічна готовність до соиіальної взаємодії в освіті [Відео]. Yоuтube. https://www.youtube.com/watch?v=1vJll5FdO4o

Харченко, Н.В. (2020, 31 березня). Дієві прийоми розвитку критичного мислення [Відео]. YouTube. https://www.youtube.com/watch?v=CNgKAyPiwLc

\title{
DIGEST OF ONLINE EVENTS OF THE INSTITUTE OF PROBLEMS ON EDUCATION OF THE NATIONAL ACADEMY OF EDUCATIONAL SCIENCES OF UKRAINE
}

\author{
Ruslan Malynoshevskyi \\ PhD in Pedagogy, Senior Researcher, Deputy Director for Scientific Work, Institute of Problems \\ on Education of the National Academy of Educational Sciences of Ukraine, Kyiv, Ukraine
}

\begin{abstract}
The Institute of Problems on Education of the National Academy of Educational Sciences of Ukraine, as well as every scientific institution in Ukraine, under the COVID-19 pandemic should radically transform its operational activities. The quarantine activities have caused to transfer most of the scientific activity into virtual space, however, scientific activity had unfolded in terms of physical time and space until recently. Forced and inevitable digitization has contributed to the complete application of the opportunities caused by the closure of education institutions for the period of quarantine, social distance, and prohibition of mass events. Subsequently, in such circumstances, the researchers of the Institute of Problems on Education of NAES of Ukraine has launched a systematic scientific communication with teachers and parents through the official Facebook page and YouTube channel. As a matter of fact, this article is a brief digest of the scientific activity during more than 30 days of quarantine.

Keywords: webinar; Institute of Problems on Education of NAES of Ukraine; preschool education; critical thinking; online learning; sustainable development goals.
\end{abstract}

